\title{
The current state of pond snail Lymnaea stagnalis (Gastropoda, Pulmonata) populations from water reservoirs of the Chernobyl nuclear accident zone
}

\author{
A. Golubev ${ }^{1}$, V. Afonin ${ }^{2}$, S.Maksimova ${ }^{3}$ and V. Androsov ${ }^{1}$ \\ ${ }^{1}$ International Sakharov Environmental University, 220009 Minsk, Belarus \\ ${ }^{2}$ Institute of Genetics \& Cytology, National Academy of Sciences of Belarus, 220072 Minsk, Belarus \\ ${ }^{3}$ Institute of Zoology, National Academy of Sciences of Belarus, 220072 Minsk, Belarus
}

\begin{abstract}
A comparative assessment of physiological and cygotenetical parameters in Lymnaea stagnalis populations from Perstok lake and the inlet of Pripyat river with the highest in Belarus and moderate levels of radioactive contamination have been carried out. In $2004 \mathrm{f} \gamma$-activity of snails from river and lake amounted to 39.2 and $567.8 \mathrm{~Bq} \mathrm{~kg}^{-1}$, respectively, and $\beta$-activity - to 123.4 and $7055 \mathrm{~Bq} \mathrm{~kg}^{-1}$ respectively. Snails from the lake were characterized by the increase of the cells with cytogenetic damages (micronuclei) and by the decrease of cells with interphase death and proportion of young cells in hemolymph. It indicates the unfavourable environmental conditions in the lake due to increased level of radioactive contamination. Nevertheless, the embryonic mortality in the progeny of the snails from lake was lower and the average population radioresistance of snails much higher than that in the river indicating intensification of the radioadaptation processes in populations from the lake.
\end{abstract}

\section{INTRODUCTION}

Long-term organisms exposure of ionizing radiation in water reservoirs of the Chernobyl nuclear accident zone (CZ) leads to different disturbances of their life cycle, accumulation of latent genetic effects and mutations which may manifest themselves in subsequent generations. On the other hand, processes of radioadaptation at different levels of biological organization are observed in some species from the CZ. Pond snail Lymnaea stagnalis is the dominating species in many CZ reservoirs inhabiting coastal and bottom biotopes the most contaminated by radionuclides. It is able to accumulate radionuclides from the water and bottom sediments. The comparative studies on physiological and cytogenetical processes in this species from reservoirs with different radiocontamination levels make it possible to demonstrate fundamental mechanisms of adaptation to the radiations.

\section{MATERIAL AND METHODS}

\subsection{Model reservoirs}

The investigations were made with $L$. stagnalis populations from two reservoirs in the Belarusian sector of CZ - inlet of the Pripyat river and Perstok lake. From summer of 1986 and up to summer of $2004 \gamma$ - and $\beta$-radionuclide contents were determined in snails from both reservoirs. The levels of $\beta$ - and $\gamma$-radiation above the soil and water surface as well as the equivalent $\gamma$-radiation dose in adjacent coastal biotopes have been measured too.

\subsubsection{Inlet of the Pripjat river}

It is located at the the distance of $18 \mathrm{~km}$ from the Chernobyl nuclear power station. Its geographical coordinates are $51^{\circ} 32.455^{\prime} \mathrm{N}$ and $29^{\circ} 52.751^{\prime} \mathrm{E}$. The inlet is due to fast water exchange due to substantial 
seasonal and perennial variations in the water level (up to $5-7 \mathrm{~m}$ ). The maximal water level is observed during spring flood-time, the minimum one - at the end of summer - at the beginning of autumn.

\subsubsection{Perstok lake}

It is located in the flood-lands of the Pripyat at the distance of $14 \mathrm{~km}$ of Chernobyl nuclear power station. Its geographical coordinates are $51^{\circ} 31.018^{\prime} \mathrm{N}$ and $30^{\circ} 01.150^{\prime} \mathrm{E}$. The average area of lake is $0.90 \mathrm{~km}^{2}$, for a maximal depth of $1.6 \mathrm{~m}$. It belongs to a water-accumulative genetic type, is non-flowing and fed primarily by spring flood and ground waters as well as by atmospheric precipitation.

\subsection{Determination of biologic parameters characterizing radioadaptation processes}

Adult snails with shell height of $25-35 \mathrm{~mm}$ were caught from both reservoirs in the summer - autumn periods of $2002-2003$ and transferred to the laboratory. There they were kept in groups of 8 to 10 individuals in aquaria of 31 capacity to obtain egg masses. Egg masses were cultivated individually at temperatures from 20 to $22^{\circ} \mathrm{C}$ until complete releases all newborns. For each egg mass the dates of their producing and all newborn release and the number of the dead embryos were recorded.

Hemolymph was obtained from the part of adult individuals from both reservoirs after 2-3 weeks of rearing in laboratory. The structure of cell population of hemolymph (percentage of different types of cells in it), the presence cells with cytogenetic damages - with micronuclei, condensation and fragmentation of nuclear chromatin, pyknosis, budding (apoptotic bodies) were determined with the help of conventional methods [1].

The radioresistance has been determined in an other group of adults. They were subjected experimentally to irradiation of $\gamma$-rays in sublethal dose of $500 \mathrm{~Gy}$ (period of irradiation $-15 \mathrm{~min}$ ). The terms of elimination of each individual were recorded as LD50.

\section{RESULTS}

\subsection{Long-term dynamics of radioactive contamination in the model reservoirs}

In $1990-1996$ the values of bottom sediment $\gamma$-activity (for ${ }^{37} \mathrm{Cs}$ ) in the coastal zone of the Pripyat inlet were notable for substantial patchiness and irregular variations within very wide limits - from 60 to $9410 \mathrm{kBq} \mathrm{m}^{-2}$ (Fig. 1a). However, these values dropped to $17.6-38.6 \mathrm{kBq} \mathrm{m}^{-2}$ by $1997-1999$. Over the period from 1992 to 1996 the $\gamma$-activity of bottom sediments in the littoral zone of Perstok lake varied within $60-4678 \mathrm{kBq} \mathrm{m}^{-2}$ and in $1997-1998$ it remained still at a very high level - up to $2186-2996 \mathrm{kBq} \mathrm{m}^{-2}$

The current levels of the equivalent $\gamma$-radiation dose in the adjacent locality, radionuclide concentration in water and bottom sediments in both reservoirs are given in Table 1.

At present, the Perstok lake is the most radiocontaminated reservoir in the Belarusian sector of the CZ. On the contrary the inlet of Pripyat river is characterized by the moderate level of radioactive contamination.

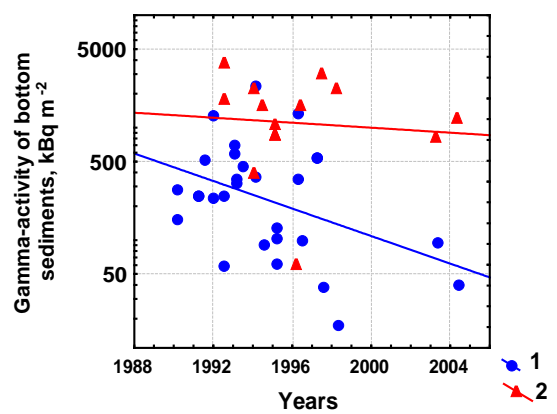

a)

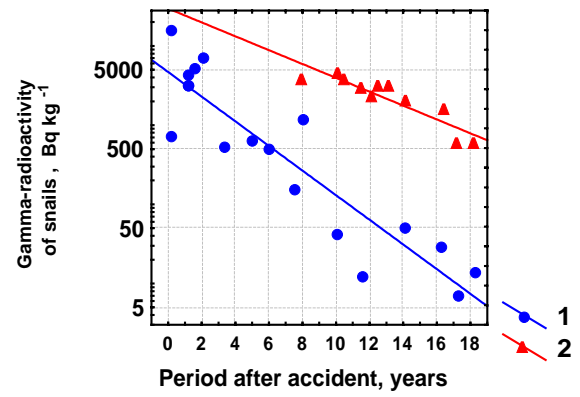

b)

Figure 1. Long-term dymanics of $\gamma$-activity of bottom sediments (a) and snails (b). 1-the Pripyat inlet; 2-Perstok lake. 
Considerable differences in dymanics and levels of bottom sediment radiocontamination in both reservoirs were caused by their different hydrological regime. On the Pripyat inlet along with natural decay of radioactive isotopes, their regular wash-out from bottom sediments with the river flow and drift down stream take place. On the contrary, in the non-flowing Perstok lake the decay of radioisotopes is compensated to a certain extent by the regular supply from the surface soil layer of adjacent areas together with water from melted snow and rains.

\subsection{Long-term radiocontamination dynamics of Lymnaea stagnalis}

The highest level of $\gamma$-active contamination in L. stagnalis from reservoirs of CZ (up to $16.3 \mathrm{kBq} \mathrm{kg}^{-1}$ wet mass) was stated in $1-2$ years after the Chernobyl accident in $1987-1988$. It is explained that the duration of life cycle in this species does not exceed 2 years, therefore snails by the end of their life cycle were able to accumulate the maximal amount of radionuclides. In the subsequent years the level of their $\gamma$-activity (determined primarily by ${ }^{137} \mathrm{Cs}$ content) was decreasing steadily (Fig. 1b).

Reduction in $\gamma$-activity $\left(Q_{t}\right)$ in L. stagnalis from the both reservoirs over the period of $1987-2004$ is satisfactory approximated with an exponential function:

$$
Q_{t}=Q_{o} e^{-k t},
$$

where $t$ - is the period of time after the nuclear accident (years, counting from May 1, 1986), $Q_{0}$ - maximal $\gamma$-activity value $\left(\mathrm{Bq} \mathrm{kg}^{-1}\right.$ wet mass) in the first $1-2$ years after the nuclear accident, $k$ - rate of decrease with time $\left(\right.$ year $\left.^{-1}\right)$.

Table 1. Radioactive contamination of model reservoirs and snails in July 2004.

\begin{tabular}{|c|c|c|c|c|}
\hline \multirow{2}{*}{ Parameter } & \multicolumn{2}{|c|}{ Inlet of the Pripjat river } & \multicolumn{2}{|c|}{ Perstok lake } \\
\hline & Biotope $1 *$ & Biotope $2 * *$ & Biotope $1 *$ & Biotope $2 * *$ \\
\hline \multicolumn{5}{|c|}{ Equivalent dose of $\gamma$-radiation (by ${ }^{137} \mathrm{Cs}$ ) on adjacent area, $\mathrm{mcSv}$ hour ${ }^{-1}$} \\
\hline Surroundings of reservoir & 1,21 & 1,21 & 3,40 & 3,40 \\
\hline Shore line & 0,18 & 0,26 & 1,30 & 1,38 \\
\hline $\begin{array}{l}1 \mathrm{~m} \text { from the shore line to the } \\
\text { centre of reservoir }\end{array}$ & 0,17 & 0,25 & 0,70 & 0,98 \\
\hline \multicolumn{5}{|c|}{$\beta$-radiation at the height of $2-3 \mathrm{~cm}$ above the water surface, impulses $\mathrm{cm}^{-2} \mathrm{~min}^{-1}$} \\
\hline Shore line & 23,40 & 32,28 & 193,1 & 468,8 \\
\hline $\begin{array}{l}1 \mathrm{~m} \text { from the shore line to the } \\
\text { centre of reservoir }\end{array}$ & 19,01 & 29,22 & 76,7 & 195,5 \\
\hline \multicolumn{5}{|c|}{ Radioactivity of bottom sediments***, $\mathrm{kBq} \mathrm{\textrm {m } ^ { - 2 }}$} \\
\hline${ }^{137} \mathrm{Cs}$ & $40.6 \pm 8.1 * * * *$ & $37.4 \pm 7.5$ & $364.1 \pm 76.5$ & $1975 \pm 395$ \\
\hline${ }^{90} \mathrm{Sr}$ & \multicolumn{4}{|c|}{ The content is lower than the instrument sensitivity } \\
\hline \multicolumn{5}{|c|}{ Radioactivity of water, $\mathrm{Bq}^{-1}$} \\
\hline${ }^{137} \mathrm{Cs}$ & $5,0 \pm 1,9$ & $4,8 \pm 1,9$ & $19,3 \pm 4,7$ & $13,9 \pm 3,8$ \\
\hline${ }^{90} \mathrm{Sr}$ & $21,2 \pm 9,2$ & $24,3 \pm 9,5$ & $3,1 \pm 10,9$ & $13,4 \pm 11,2$ \\
\hline \multicolumn{5}{|c|}{ Radioactivity of snails, $\mathrm{Bq} \mathrm{kg}^{-1}$ wet mass } \\
\hline${ }^{137} \mathrm{Cs}$ & \multicolumn{2}{|c|}{$39,2 \pm 10,1$} & \multicolumn{2}{|c|}{$567,8 \pm 131,0$} \\
\hline${ }^{90} \mathrm{Sr}$ & \multicolumn{2}{|c|}{$123,4 \pm 25,9$} & \multicolumn{2}{|c|}{$7055 \pm 141,4$} \\
\hline
\end{tabular}


The equation (1) for L. stagnalis from the Pripyat inlet for the period 1987 - 2004 has the following form:

$$
Q_{t}=6038 e^{-0379 t}
$$

with the correlation coefficient (r) between $\ln Q_{t}$ and $t$ equal to $-0,903$. The equation (1) for the same species from Perstok lake for the period $1990-2004$ is of the following form:

$$
Q_{t}=29648 e^{-0,292 t}
$$

with $\mathrm{r}=-0,915$.

At present content of $\beta$-isotope ${ }^{90} \mathrm{Sr}$ in snails from two populations is much higher than those of $\gamma$-isotope ${ }^{137} \mathrm{Cs}$. It is obvious that they absorb ${ }^{90} \mathrm{Sr}$ from the water but not from the bottom sediments.

A slight positive correlation between the $\gamma$-radionuclide content in bottom sediments (BS, $\mathrm{kBq} \mathrm{m}^{-2}$ ) and in bodies of snails $\left(\mathrm{Q}, \mathrm{Bq} \mathrm{kg}{ }^{-1}\right)$ from both reservoirs (Fig. 2) have been established for the period of $1990-2004$. It can be expressed by the equation: $\mathrm{Q}=742+0.522 \mathrm{BS}$, with $\mathrm{r}=0,398$

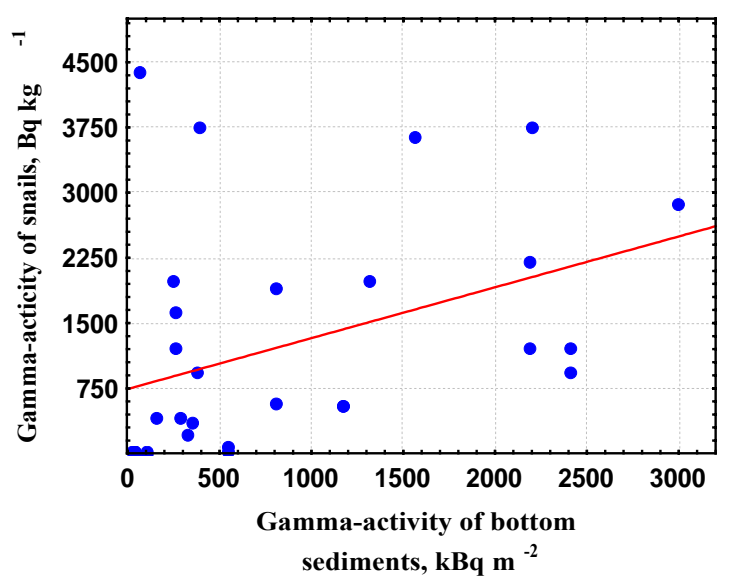

Figure 2. Correlation between concentration of $\gamma$-radionuclides in bottom sediments and in bodies of L. stagnalis from both reservoirs in $\mathrm{CZ}$.

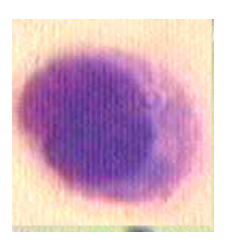

a

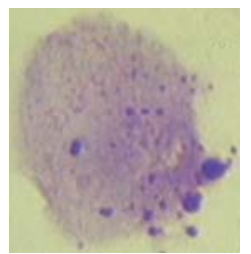

d

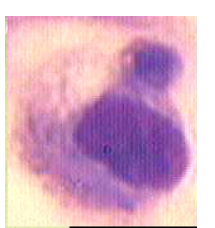

b

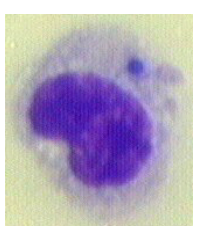

c

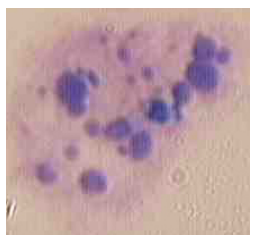

e
Figure 3. Cytogenetic damages in amoebocytes: a - norm; b, c - cells with micronuclei; $\mathrm{d}$ - interphase cell death; e - mitotic cell death.

\subsection{Embryonic mortality}

Nine egg snail masses have been derived from each reservoir. Among them embryonic development was observed in eight masses produced by snails from Perstok lake and in five from the Pripyat inlet. In those egg masses where embryonic development took place, the average survival of embryos in egg masses produced by mollusks from Perstok lake $(86.7 \%)$ was higher than in those from the Pripyat inlet (74.4\%). The average duration of embryogenesis in egg masses of snails from the Pripyat inlet $(20.4 \pm 4.8$ days $)$ and Perstok lake $(19.3 \pm 4.9$ days $)$ differed insignificantly $(P>0.050)$.

\subsection{Cytogenetic damages}

The number of cells with micronuclei (Fig. 3b, c) were determined to relate directly radionuclid concentration in snail bodies and in the reservoirs, which they inhabit (Table 2). The level of apoptosis depends on season and year. It results in changes in subpopulation composition of hemolymph cells. Changes in relative content of cell pools differing in sensitivity to apoptosis induction lead to change in proportion between the levels of death cells and cells with cytogenetic injuries. 
Table 2. Levels of death cells and cells with cytogenetic injuries in cell population of hemolymph of L. stagnalis.

\begin{tabular}{|c|c|c|c|c|}
\hline Reservoir & $\begin{array}{c}\text { Animals } \\
\text { examined }\end{array}$ & Cells examined & Cells with micronuclei, \% & $\begin{array}{c}\text { Cells with features of } \\
\text { apoptosis, \% }\end{array}$ \\
\hline \multicolumn{5}{|c|}{ Summer 2002 } \\
\hline Pripyat inlet & 3 & 3300 & $0,94 \pm 0,17$ & $1,42 \pm 1,02^{*}$ \\
\hline Perstok lake & 4 & 4000 & $1,72 \pm 0,21$ & $0,68 \pm 0,32^{*}$ \\
\hline \multicolumn{5}{|c|}{ Autumn 2002 } \\
\hline Pripyat inlet & 5 & 5200 & $1,54 \pm 0,30$ & $0,67 \pm 0,24 *$ \\
\hline \multicolumn{7}{|c|}{ Summer 2003. } \\
\hline Pripyat inlet & 10 & 7309 & $0,24 \pm 0,06$ & $0,04 \pm 0,02^{* *}$ \\
\hline Perstok lake & 10 & 7208 & $0,75 \pm 0,19$ & $0,28 \pm 0,08^{* *}$ \\
\hline
\end{tabular}

* chromatin fragmentation and condensation (Fig. 3 d), piknosis, budding and apoptotic cells; ** mitotic catastrophes (chromatin fragmentation at G2/M stage) (Fig. 3 e)

\subsection{The state of immune system}

The function of immune system in L. stagnalis is performed by cells of mantle cavity liquid (hemolymph). Immune cells, exhibiting high proliferation and heterogeneity allow estimating organism response to damaging factors by the changes of levels of their differentiation, mortality and cytogenetic stability. There is a single type of form elements - amoebocytes in hemolymph of this species. They can be subdivided into granular and agranular amoebocytes, or correspondingly -- granulocytes and agranulocytes. The previous are functionally active elements which react to the changes in the physiological state of organism under the effect of adverse external factors morphologically and numerically. In their turn, agranulocytes are subdivided into small and large ones (diameter is $2-6$ and $7-12 \mathrm{mcm}$, respectively), the previous type a main part of hemolymph cell population.

In 2002 in the cell population of hemolymph of individuals from the Pripyat inlet a percentage of granulocytes was $32 \%$, that of necrotic cells $-10 \%$ and of young amoebocyte forms $-5 \%$. In 2003 the same parameter of granulocytes increased to $41 \%$ and that of young amoebocytes to $9 \%$, while the percentage of necrotic sells decreased to $8 \%$.

In 2003 in hemolymph of individuals from Perstok lake the percentage of granulocytes was $24 \%$ and that of necrotic cells $-21 \%$. In 2003 a slight increase in percentage of necrotic cells (to $25 \%$ ) was revealed. The number of young cells decreased (to $2 \%$ ) and the percentage of granulocytes remained at the level of the last year of $24 \%$.

Besides, formation of a large quantity of different cytoplasm evaginations was found in large and small granulocytes of individuals from Perstok lake. Other negative morphological changes such as cytoplasmic evaginations and necrosis occurred in small agranulocytes.

\subsection{Radioresistance}

One of the most important integral indices of organism radioadaptation level is their survival at sublethal doses of ionizing radiation. Assessment of long-term variations of this parameter in natural populations allows you to determine the trends and dynamics of radioadaptation processes.

Considerable individual variability on radioresistance in L. stagnalis populations has been established in all cases (Table 3). The average value of duration survival after irradiation (DR) in 2002 for population from Perstok (31.7 days) is significantly higher than those for population from Pripyat for the whole period of investigations. The individuals in each experiment can be divided into two groups according to the terms of their elimination after irradiation. The first group has already eliminated at the 
first 1 - 4 days. The second group has eliminated noticeable later and the individuals with intermediate terms of elimination were practically absent. The specimen eliminated at the second group can be mentioned conventionally as "radiomutants". They were able even after irradiation of 500 Gy dose in experiment to produce egg masses from which quite viable newborns later emerged [2].

Radiodioresistance of L. stagnalis populations from "clean" (noncontaminated by radionuclides) reservoirs out of $\mathrm{CZ}$ is considerable lower. For example, average values of DR for several populations from Belarus and Poland were within the limits 5.4 - 7.8 days, with maximal values for "radiomutants" - up to 9 - 14 days in 1991 - 2000. The percentage of the previous in the populations from "clean" reservoirs does not exceed $30-35 \%$.

Table 3. The duration of survival (DR) after irradiation of $\gamma$-rays in dose of $500 \mathrm{~Gy}$ of snails from both reservoirs.

\begin{tabular}{|c|c|c|c|c|c|}
\hline Reservoir, year & $\begin{array}{c}\gamma \text {-radiocontamination } \\
\text { of snails, } \mathrm{Bq} \mathrm{kg}^{-1}\end{array}$ & $\begin{array}{c}\mathrm{DR}_{\text {min }}-\mathrm{DR}_{\max }, \\
\text { days }\end{array}$ & $\begin{array}{c}\text { Average } \\
\mathrm{DR} \pm \sigma, \text { days }\end{array}$ & $\begin{array}{c}\text { LD-50, } \\
\text { days }\end{array}$ & $\begin{array}{c}\% \% \text { of } \\
\text { "radiomutants" }\end{array}$ \\
\hline Pripyat inlet, 1991 & 651 & $1-24$ & $9,2 \pm 7,05$ & 11,0 & 60.0 \\
\hline Pripyat inlet, 1992 & 502 & $1-15$ & $9,9 \pm 4,50$ & 11,0 & 55.0 \\
\hline Pripyat inlet, 2002 & 29,3 & $1-13$ & $10,3 \pm 2,67$ & 11,0 & 68.0 \\
\hline Pripyat inlet, 2003 & 7,2 & $1-19$ & $4,1 \pm 4,26$ & 2,0 & 9,1 \\
\hline Perstok lake, 2002 & 1560 & $1-54$ & $31,7 \pm 15,4$ & 34,0 & 87,5 \\
\hline Perstok lake, 2003 & 585 & $1-50$ & $11,9 \pm 10,6$ & 10,5 & 76,2 \\
\hline
\end{tabular}

\section{DISCUSSION}

Radiocontamination levels of model reservoirs and snail populations inhabiting them reached the maximum in $1987-1988$, after that they steadily decreased. The period of twofold decrease in the $\gamma$-activity $\left(t_{Q / 2}=\ln 2 / k\right)$ for $L$. stagnalis from the Pripyat inlet is approximately 1.8 years that is well consistent with the average period of half-life period of $\gamma$-isotope complex released as a result of the accident. Nevertheless, the $\gamma$-activity of snails from both reservoirs still considerably exceeded its natural level - no more than $4-8 \mathrm{~Bq} \mathrm{~kg}^{-1}$ in summer 2004. If such a tendency remains, the $\gamma$-radionuclide content in molluscs from this reservoir will have already dropped practically to their natural level by $2007-2010$. On the contrary, in Perstok lake $\left(t_{Q / 2}=3.4\right.$ years $)$ this value will remain at the very high level in the nearest years with a tendency to a small decrease. At present $\beta$-isotope ${ }^{90} \mathrm{Sr}$ is a major dose-forming factor of external and internal irradiation for L. stagnalis in both reservoirs of $\mathrm{CZ}$, since its concentration in organisms is much higher than of $\gamma$-isotope ${ }^{137} \mathrm{Cs}$. At that ${ }^{137} \mathrm{Cs}$ is concentrated predominantly in metabolically active soft tissues and can be removed from organism easily. On the contrary, ${ }^{90} \mathrm{Sr}$ is concentrated in metabolically low-active shells from which it is not removed practically.

Chronicle radiation exposure exerts a distinct negative effect on the physiological state of L. stagnalis populations in both reservoirs. Degree of this impact is increasing with a rise of the levels of radioactive contamination both of reservoirs and snails. As compared with those from the Pripyat in $2002-2003$, an increase in the percentage of dead cells and decrease of young ones was observed in the hemolymph cell population of snails from Perstok lake. The percentage of cells with cytogenetic damages (micronuclei, etc.) in hemolymph of snails from Perstok lake was higher than those of snails from the Pripyat inlet too. This fact indicates an unfavourable ecological situation for L. stagnalis in Perstok lake caused by chronic effect of very high radiocontamination of this reservoir.

Along with this, evident signs of radioadaptation were revealed in the populations L. stagnalis from both reservoirs. For example, the mortality of embryos and egg masses produced by the snails from Perstok lake was lower than those from the Pripyat inlet, although the level of radiocontamination of the former reservoir is much higher. 
Not all the DNA damages induced by radioactive irradiation are realized in cytogenetic lesion. This often leads to the activation of the genetically determined program for elimination of affected cells (apoptosis). Long-term existence of L. stagnalis population in Perstok lake resulted in reducing of cells sensitivity, it led to rapid interphase death and an increase number of cells with micronuclei. An increase cells percentage of with signs of "mitotic/delayed mitotic" death [3] in the whole cell population that can be regarded as adaptation at the molecular-genetic level to an increased radiation background [4].

Radioadaptation processes taking place at the molecular-genetic level lead to an increase in total organism radioresistance. A significant increase in the average radioresistance in the Pripyat inlet L. stagnalis population as against those from "clean" reservoirs was already noted by 1991 . Over the next 10 years this value did not undergo marked changes towards a decrease.

However, this parameter dropped up to its value for populations from "clean" reservoirs in 2002. The decrease of total radioresistance of Pripyat population of L. stagnalis descended from the reduction proportion of "radiomutants" in it. In the whole, the longstanding changes of the average radioresistance of $L$. stagnalis populations from both reservoirs correlate positively with the dynamics of the radiocontamination of snails and bottom sediments.

Obviously, population L. stagnalis from Perstok lake have been exposed under much more strict natural selection on increasing of radioresistance. Very high level of radiocontamination there contributes to rapid elimination of individuals less persistent to this factor and preferred survival of "radiomutants", therefore the current radioresistance level (by 2003) of this population being much higher than that from the Pripyat inlet. In connection with a decrease in the total radiocontamination level of the Pripyat, one should expect further gradual loss of radioadaptation in the local population in subsequent years. However, the degree of radioadaptation in the Pestok population will remain very high even over a long period of time.

\section{Acknowledgments}

The authors are grateful to V. Kalinin (ISEU, Minsk) for technical assistance in determination of radioactivity of collected samples.

\section{References}

[1] Studzinsku G.P. Ed. Cell Growth and Apoptosis. A practical approach. Oxford University press. 1995.

[2] Golubev A.P. Proc. Rus. Acad. Sci.1995. Volume 342, pp. 280-283 (In Russian).

[3] Radford I.R., Murphy T.K. Int. J. Radiat. Biol. 1994. Volume 65, pp. 229-239

[4] Wang L. et al. Radiat. Res. 1996.Volume 146, pp. 259-266. 